\title{
Drying kinetics of RDF: Experimental investigation and modeling
}

\author{
Karolina Słomka-Polonis ${ }^{1, *}$, Bogusława Kordon-Łapczyńska ${ }^{1}$, and Jarosław Frączek ${ }^{1}$ \\ ${ }^{1}$ Department of Mechanical Engineering and Agrophysics, Faculty of Production and Power Engineeing \\ University of Agriculture in Kraków, Poland
}

\begin{abstract}
An experimental study was performed to determine the drying characteristics of an oversized fraction of RDF alternative fuel using a laboratory scale hot air dryer at a variety air temperatures and a constant air velocity. For this research the industrial RDF was derived from a Regional Municipal Waste Treatment Facility near the city of Kraków, Poland. The samples of RDF were prepared in two forms: ovesized (unmodified condition) and shreded in a two-drum crusher. In addition, the RDF was sorted into three groups of samples: paper, plastic, textiles. Each form of RDF and each group of samples were dried in hot air dryer at temperatures of $50,70 \mathrm{i} 90{ }^{\circ} \mathrm{C}$ and a constant air velocity of $1,5\left[\mathrm{~m} \cdot \mathrm{s}^{-1}\right]$. The loss of the the samples mass were measured in a continues manner until the equilibrum moisture content was reached. The effective moisture diffusivity $\left[\mathrm{m}^{2} \cdot \mathrm{s}^{-1}\right]$ and activation energies $\left[\mathrm{kJ} \cdot \mathrm{mol}^{-1}\right]$ was amounted. The analysis of the course of moisture content change concludes that that the drying of the RDF alternative fuel occured mainly in the II period of the process during which the transport of water content was carried out by diffusion. And, to a lesser extent, with the surface heat transfer in II period. Based on the calculated data there was a model determined which presented the best possible matching of the course of moisture content change.
\end{abstract}

\section{Introduction}

RDF alternative fuel is a combustible fraction of municipal or industrial waste obtained from the separation of the biodegradable fraction. It is typically produced in the Regional Waste Water Treatment Plant (RIPOK). RDF is a heterogeneous fuel whose main components are paper (including cardboard), plastic and textiles [1]. RDF can also be found in admixtures of inert components: glass, wood, organic parts and metals. Their presence is due to an imperfection of the municipal waste screening process. The mass fraction of individual fractions varies, depending on the installation, source of waste: Municipal Solid Waste (MSW), Commercial and Industrial Waste (CIW), Construction and Demolition Waste (CDW) and collection sites: urban and rural $[2,3$, 4]. Typically, RDF is dominated by paper: $50-70 \%$, plastic: $30-50 \%$, textiles $(<10 \%)$ and inert ingredients $(<5 \%)$. An example of RDF composition according to the source of waste is presented in the Table 1 .

The RDF calorific value varies between $\mathrm{MJ} \cdot \mathrm{kg}^{-1}$ [4]. RDF humidity varies, ranging between $5-23 \%[3,4]$. This depends on the origin of the waste, the type of screening plant and the time of year for municipal waste collection $[6,7]$. The RDF fuel surplus fraction consists of particles greater than $5 \mathrm{~cm}$ [8]. It is generated by screening a mechanical waste stream of municipal waste on sieve screens (drum sieves). The particle size depends on the mesh size and typical sieve sizes are $5,8,10 \mathrm{~cm}$ [9].

RDF can be utilized thermally in combustion, pyrolysis and gasification. Most often it is a product intended for cement kilns, lime plants, waste incineration plants and power plants as well as heating plants [10]. $\mathrm{RDF}$ is also subjected to the process of pelleting or briquetting [11]. The moisture content parameter plays an essential role in the design and process optimisation of thermal ultilisation or compaction of the RDF fuel. The presence of moisture has a great impact on the fuel's calorific value and, consequently, on the possibilities of thermal processing. For example, for a cement kiln, humidity cannot exceed $15 \%$ [12]. On the other hand, RDF with low moisture content is difficult to handle during transportation within facilities due to dust and blockages on conveyor belts. Moisture also plays a key role in the agglomeration process. Water molecules are involved in the physical-chemical reactions which occur during bonding of fuel elements (adhesion, formation of solid bridges) [13]. However, the water molecules are uncompressible, which at the same time makes the compaction process quite difficult. Too high water content will result in a high relaxation coefficient [14], but too low will increase the energy efficency of the shredding process [15] and increase the risk of spontaneous combustion as well [16]. Determining the required humidity ought to be a compromise between the

* Corresponding author: karolina.slomka-polonis@,urk.edu.pl 
production process and the disposal of the fuel concerned.

Table 1. Composition of RDF/SRF [3].

\begin{tabular}{|c|c|c|c|}
\hline \multirow{2}{*}{$\begin{array}{c}\text { Waste } \\
\text { component }\end{array}$} & \multicolumn{3}{|c|}{ SRF: } \\
\hline & $\begin{array}{l}\text { C\&IW } \\
{[w t \% *]}\end{array}$ & $\begin{array}{l}\text { CDW } \\
{[\mathbf{w t} \%]}\end{array}$ & $\begin{array}{l}\text { MSW } \\
{[\mathbf{w t} \%]}\end{array}$ \\
\hline Paper and & 35.6 & 22.0 & 30.0 \\
\hline cardboard & 24.0 & 6.8 & 19.6 \\
\hline Plastic (soft) & 16.5 & 9.2 & 13.0 \\
\hline Plastic (hard) & 8.5 & 6.0 & 10.0 \\
\hline Textile & 6.4 & 38.0 & 8.2 \\
\hline Wood & - & - & 0.4 \\
\hline Bio Waste & 1.0 & 2.4 & 2.2 \\
\hline Rubber & 1.2 & 0.5 & 2.6 \\
\hline Foam & 0.8 & 0.5 & 0.5 \\
\hline Metal & 0 & 2.0 & 0.7 \\
\hline Glass & 0 & 0.6 & 0 \\
\hline Stone & 6.0 & 11.0 & 12.8 \\
\hline Fines & & & \\
\hline
\end{tabular}

Thermal drying to reduce water content has been proved to be an effective method [17]. In many branches of industry, drying has a crucial role: food industry, agriculture, paper industry. There are many methods of drying available: contact, convection, microwave, radiation, dielectric and others [18]. Drying consists by removing moisture from the material through evaporating water, with the share of heat supplied to this process. The most common and simplest method is drying by convection using gas, usually warm air, as a drying medium. In this process, the transport of heat and mass from the interior of the material to its surface is carried out by diffusion, and further on into the surrounding atmosphere by convection. Drying also can be a part of the process, taking part in the preparation of the raw material for the compaction process of solid biofuels [19], and yet is a very energy consuming process. Since RDF is a heterogeneous material composed of many different components, it contains different types of moisture. The paper and textiles would propably be the main water binding materials in alternative fuel [20]. The water contained there would be primarily capillary bounded, while in the plastics the moisture would be collected as a film on the surface. The RDF is a lightweight, porous and bulky material, so convective drying would have a more practical effect due to the ease of flow of the drying medium between the RDF elements. Knowing the drying kinetics has a key role in designing and optimization for the agglomeration or thermochemical processing of raw materials [21]. There are articles concerning drying of paper, paper sludge [i.e. 22, 23, 24], textiles [25] or food waste [26]. These research studies focused on drying kinetics analysis, drying curves analysis, the Effective moisture diffusivity $\left(D_{\text {eff }}\right)$ and Activation energies $\left(E_{a}\right)$ determinations and calculations the best equation for the drying procces under variable factors (i.e. temperature of drying, air velocity, initial moisture content of the sample). However very little is said in the literature concerning RDF drying. The purpose of this study is to observe the effect of various temperatures at convection drying on the drying kinetics of RDF and it's main fractions (plastic, textiles and paper) in separation.

\section{Material and methods}

RDF was collected from the RIPOK industrial plant located in Krakow, which was produced from municipal solid waste sorted out of the Krakow area. The analysed fraction was formed on drum sieve with a $10 \mathrm{~cm}$ mesh screen installed. Because of that the RDF is mainly composed of large particles (over $3 \mathrm{~cm}$ ).

Table 2. Composition of presented RDF [27].

\begin{tabular}{ll}
\hline Waste component & wt\% \\
\hline plastics & 87.44 \\
paper, wood and similar & 5.09 \\
textiles & 2.60 \\
biomass & 1.56 \\
glass & 0.64 \\
metal & 0.49 \\
hazardous waste & 0.00 \\
other, non-combustible & 2.17 \\
\hline " wt\%=wt\% percentage by weight (ratio ofmass to totalmass)
\end{tabular}

There were five types of samples prepared for the experiment:

- RDF0 - primary fine fraction gained directly from RIPOK

- RDF1 -primary fraction, shredded in a two-drum crusher on the RDF pelletizing line.

In addition, three groups of raw materials were selected from RDF0: paper, plastic and textiles.
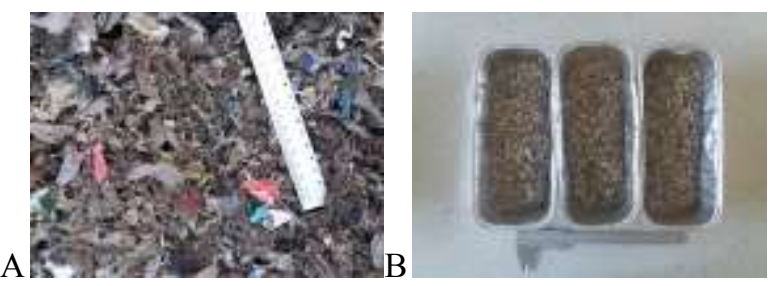

Fig. 1. Samples of RDF: A) RDF1, B) RDF0.

There were samples of $12 \mathrm{~g}( \pm 5 \mathrm{~g})$ prepared from all raw materials for drying. Samples were dried by convection in the laboratory drier Elkon KBC 65G. The measurement stand diagram is show in Fig. 2. The drying experiments were performed at 50,70 i $90{ }^{\circ} \mathrm{C}$ air temperatures. The drying air velocity was at a constant $1.5 \mathrm{~m} \cdot \mathrm{s}^{-1}$. All the experiments were replicated five times at each temperature value for each samle type. 


$$
\mathrm{MR}=\left(\mathrm{U}_{\tau}-\mathrm{U}_{\mathrm{e}}\right) \cdot\left(\mathrm{U}_{\mathrm{i}}-\mathrm{U}_{\mathrm{e}}\right)^{-1}=\exp \left(-\mathrm{k} \tau^{\mathrm{N}}\right)
$$

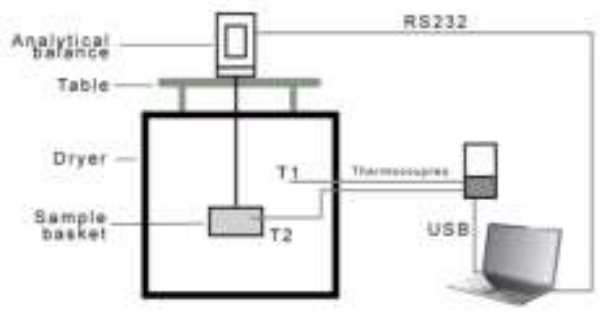

Fig. 2. Measurement stand.

The weight loss was measured by Radwag AS160.R2 analytical balance $(\mathrm{d}=0,01 \mathrm{mg})$. The measurement was recorded continuously of at $5 \mathrm{~s}$ interval and saved by the Radwag "Pomiar-Win” software each time. The temperature was measured with two NiCrNiAl thermocouples that were placed inside dryer. With a thermometer that Works in connection with the YC-747UD meter the temperature of the ambient environment- the inside of the dryer (T1) and the temperature of the sample (T2) was measured. The measurements were recorded continuously at $1 \mathrm{~s}$ intervals by Temp Monitor_S2 (ver. 1.0.16) software. The drying proces proceeded until the moisture content reached an equilibrum value (until there were no significant variations in the moisture lost). The mean drying time was 25 minutes. A Pol-Eko SLW-53 TOP dryer was used for the samples initial moisture content measurment according to the PN-EN 15414-3:2011 standard [28]. The dry matter calculations were done according to the PN-EN ISO 638:2008 standard [29].

The moisture content $\left(\mathrm{U}_{\tau}\right)$ was calculated from the following equation:

$$
U_{\tau}=\frac{m_{\tau}-m_{d b}}{m_{d b}}
$$

Where, $m_{\tau}$ is the mass of the sample at any given time $\tau,[\mathrm{kg}] ; m_{d b}$ the mass of the dry basis of the sample, $[\mathrm{kg}]$. The unit of the moisture content is $\left(\mathrm{U}_{\tau}\right) \mathrm{kg}$ water $/ \mathrm{kg}$ dry basis.

The drying rate $(\mathrm{dU} / \mathrm{dt})\left[\mathrm{kg}\right.$ water $/ \cdot \mathrm{kg}$ d.b. $\left.\cdot \mathrm{s}^{-1}\right]$ was obtained from the following equation [18]:

$$
\frac{d U_{\tau}}{d \tau}=\frac{U_{i}-U_{i+1}}{\tau_{i}-\tau_{i+1}}
$$

Where $U_{i}$ is the moisture content at $i$ th time $[\mathrm{kg}$ water $/ \mathrm{kg}$ d.b.], $U_{i+1}$ is the moisture conent at the $i+1$-th time [ $\mathrm{kg}$ water $/ \mathrm{kg} \mathrm{d}$.b.], $\tau_{i}$ and $\tau_{i+l}$ is respectively $i$ th and $i+1$-th time of the measurement [s].

The three common models were used to quantify drying kinetics of RDF0 and RDF1. The models are described with simplified equations respectively [18]:

- Henderson-Pabis:

$$
M R=\left(U_{\tau}-U_{e}\right) \cdot\left(U_{i}-U_{e}\right)^{-1}=a \exp (-k \tau)
$$

- Lewis:

$$
\mathrm{MR}=\left(\mathrm{U}_{\tau}-\mathrm{U}_{\mathrm{e}}\right) \cdot\left(\mathrm{U}_{\mathrm{i}}-\mathrm{U}_{\mathrm{e}}\right)^{-1}=\exp (-\mathrm{k} \tau)
$$

- Page:
Where, $M R$ is the moisture ratio (dimensionless), $U_{\tau}$ is the moisture content at Any given time $\tau[\mathrm{kg}$ water $/ \mathrm{kg}$ d.b.], $U_{i}$ is the initial moisture content [ $\mathrm{kg}$ water $/ \mathrm{kg} \mathrm{d.b.]}$, $U_{e}$ is the equilibrium moisture content [ $\mathrm{kg}$ water $/ \mathrm{kg} \mathrm{d}$ d.b.], $k$ is the drying rate constant $\left[\mathrm{s}^{-1}\right] . N$ and $a$ are the empirical constants.

Taking the natural $\log$ of both sides of the equations 3-5 is a way to determine the empirical constants. The form of the normalized equations of the moisture ratio versus time is:

- Henderson-Pabis:

$$
\ln (\mathrm{MR})=\ln (\mathrm{a})-\mathrm{k} \tau
$$

- Lewis:

$$
\ln (\mathrm{MR})=-\mathrm{k} \tau
$$

- Page:

$$
\ln [-\ln (\mathrm{MR})]=\ln (\mathrm{k})+\mathrm{N} \ln (\tau)
$$

The Effective moisture diffusivity $\left(\mathrm{D}_{\mathrm{eff}}\right)\left[\mathrm{m}^{2} \cdot \mathrm{s}^{-1}\right]$ can be determined from the slope of the normalized plot of the unaccomplished moisture ratio, $\ln (\mathrm{MR})$ vs time, using the following equation [31]:

$$
D_{e f f}=-\left(4 L^{2} \cdot \pi^{2}\right) \cdot k
$$

Where, $L$ is the thickness of the sample (slab) of $0,0045 \mathrm{~m}[\mathrm{~m}], k$ is the drying rate constant $\left[\mathrm{s}^{-1}\right]$.

The Activation energies $\left(\mathrm{E}_{\mathrm{a}}\right)\left[\mathrm{kJ} \cdot \mathrm{mol}^{-1}\right]$ was obtained from the reliance of the effective moisture diffusivity $\mathrm{D}_{\text {eff }}$ on the temperature $T$. The reliance can be described by an Arrhenius type equasion [31]:

$$
D_{e f f}=D_{0} \exp \left(-\frac{E_{a}}{R_{C} \cdot T}\right)
$$

Where the $D_{\text {eff }}$ is effective moisture diffusivity $\left[\mathrm{m}^{2} \cdot \mathrm{s}\right.$ ${ }^{1}$ ]; $D_{0}$ is the pre-exponential factor of the Arrhenius equation $\left[\mathrm{m}^{2} \cdot \mathrm{s}^{-1}\right], R$ is the universal gas constant $(8.3145$ $\left.\mathrm{kJ} \cdot \mathrm{mol}^{-1} \cdot \mathrm{K}^{-1}\right)$ and $T$ is the absolute air temperature $[\mathrm{K}]$. Taking natural logarithm of both sides of Eq. (5) the result can be written as:

$$
\ln \left(D_{\text {eff }}\right)=\ln \left(D_{0}\right)-\frac{F_{a}}{R_{C}} \cdot \frac{1}{T}
$$

The activation energy $\left(E_{a}\right)$ is determined by plotting the natural logarithm of $\mathrm{D}_{\text {eff }}\left(\mathrm{lnD}_{\text {eff }}\right)$ versus reciprocal of the absolute temperature $T[\mathrm{~K}]$.

The experimental drying data was tested to find the most suitable model among the above mentioned (3-5). The different constants in the considered models were determined using a linear regression procedure. The adjusted coeficient of determination $\left(\mathrm{R}^{2}\right)$, reduced chisquared $\left(\chi^{2}\right)$ and root mean square error (RMSE) were used to inspect the goodness of fit. [18]. The matemathematical model is more suitable for higher values of $R^{2}$ and lower values of $\chi^{2}$, RMSE and $\% E$. The 
following equations were used to calculate the above mentioned parameters:

$$
\begin{aligned}
& \mathrm{R}^{2}=1-\left[\frac{\sum\left(M R_{P}-\overline{M R_{E}}\right)^{2}}{\sum\left(M R_{E}-M R_{P}\right)^{2}}\right] \\
& \gamma^{2}=\frac{\sum\left(M R_{5}-M R_{P}\right)^{2}}{N-n} \\
& \text { RMSE }=\sqrt{\frac{\sum\left(M R_{P}-M R_{E}\right)^{2}}{N}}
\end{aligned}
$$

Where $M R_{P}$ is the predicted moisture ratio at any time, $M R_{E}$ is the experimental moisture ratio at any time, $\overline{M R}_{E}$ is the average experimental moisture ratio, $N$ is the number of observations, $n$ is the number of constants in the drying model.

The calculations and statistical data analysis were performed using R Core Team (2016) software (R Foundation for Statistical Computing, Vienna, Austria. URL https://www.R-project.org/) with the packages: ggpolt, dplyr, stats.

\section{Results and discussion}

The initial moisture content of all samples were determined using PN-EN 15414-3:2011 standard [29]. As expected the highest average value of moisture content was obtained for paper $(\sim 41 \%)$ and textiles $(\sim 25$ $\%)$. The plastics, that were the main component of the RDF had a moisture content of approximately $10 \%$. There was no significant differnence in the moisture content values between RDF0 and the RDF1 samples. It is clear that the mechanical comminution at the pellet production line had little impact on moisture loss in the material. (Table 3).

Table 3. Moisture content [\%] of the specific sapmles:

\begin{tabular}{cc}
\hline Sample & Moisture Content [\%] \\
\hline RDF1 & 21.9057 \\
RDF0 & 19.1831 \\
Plastic & 9.8426 \\
Paper & 41.1430 \\
Textiles & 24.7662 \\
\hline
\end{tabular}

The shapes of the drying curves versus time for the samples resembled the exponential function $\left(\mathrm{U}_{\tau}\right)$. The steeper the curve was, the quicker the moisture loss took place. It is cleary evident that these curves were influenced by various temperatures (Fig. 3, 4). The deviations were related to the individual characters of particular samples which could be also noticed in the shapes of the moisture ratio curves (Fig. 3. - bottom plots). There was no I period of drying process in the paper and textiles. In these samples the drying process began in the second period in which the diffusion mechanism is predominant, and which is mostly common for porous matter. The drying rate was going slow at the temperature of $50{ }^{\circ} \mathrm{C}$ in the paper, however at the temperature of 70 and $90{ }^{\circ} \mathrm{C}$ the rate of changes were faster (Fig. 3A, the bottom plot). The maximum drying rate of the paper was $0.06 \times 10^{-2} \mathrm{~kg}$ water $/ \mathrm{kg} \mathrm{d.b}$. at $90^{\circ} \mathrm{C}$.
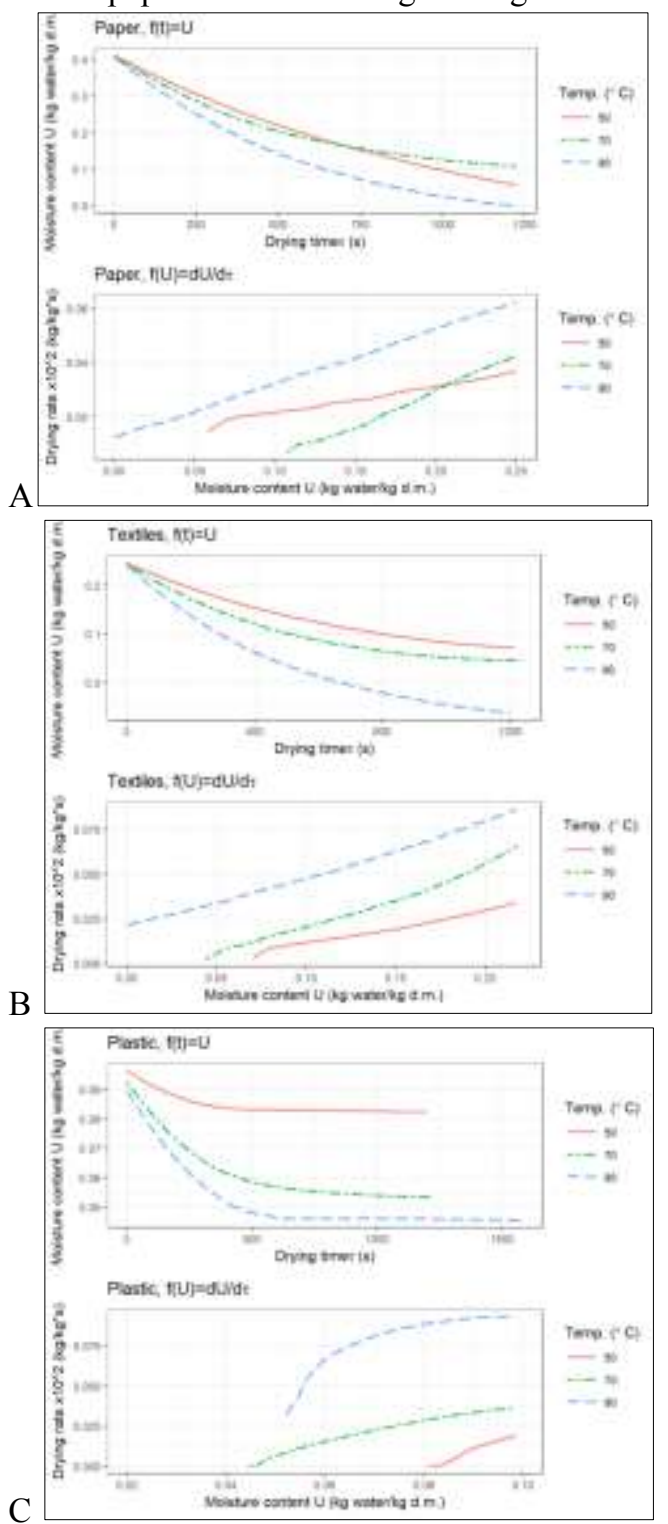

Fig. 3. Effect of drying air temperature and moisture content on the drying rate of $\mathrm{A}$ ) paper, B) textiles, C) plastic.

Considering the textiles, the drying curves are also noticeably influenced by the various temperatures. With the decreasement of water content, the drying curves are less steep. (Fig. 3B). The paper and textiles were dryed completely at the $\mathrm{U}=0$ at the temperature of $90^{\circ} \mathrm{C}$ after 20 minutes $(1250 \mathrm{~s})$. With the decreasment of the temperature the final water content in the both of samples was equal to equilibrium moisture content. The maximum drying rate of the textiles was $0,088 \times 10^{-2} \mathrm{~kg}$ water $/ \mathrm{kg}$ d.b. at $90{ }^{\circ} \mathrm{C}$.

Different kind of curve shapes can be observed in plastisc (Fig. 3C). With the decreasement of water content, the drying curves are less steep, and more flat and paralel to the $\mathrm{x}$ axis. There are two periods of drying 


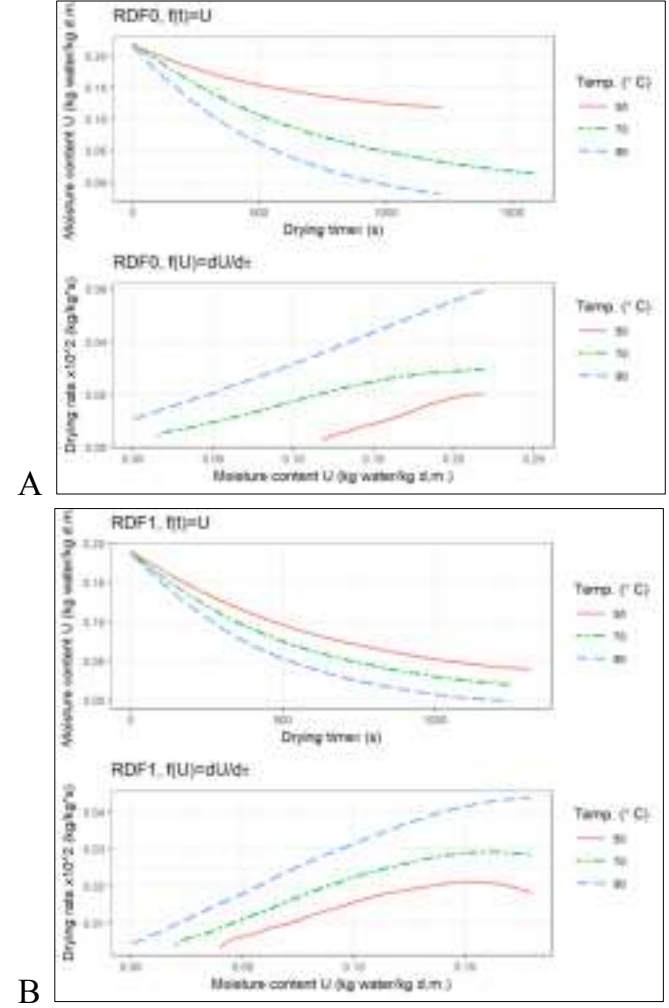

Fig. 4. Effect of drying air temperature and moisture content on the drying rate of A) RDF0, B) RDF1.

process in plastic, where I period is mild and long, and the II one is dynamic and short (especially at the temperature of $90{ }^{\circ} \mathrm{C}$ ). This is characteristic for porouscapillary and porous materials. The maximum drying rate in plastic is $0,085 \times 10^{-2} \mathrm{~kg}$ water $/ \mathrm{kg}$ d.b. at $90{ }^{\circ} \mathrm{C}$. The time of drying of $20-25$ minutes is too short to remove the water completely from the samples above at $50{ }^{\circ} \mathrm{C}$, in particular for paper and textiles. The plastic and paper exhibit characteristics of hygroscopic material at the lower temperature values, however at $90{ }^{\circ} \mathrm{C}$ the samples exhibit the characteristics close to nonhygroscopic material [32].

Based on the shapes of the drying RDF0 and RDF1curves it can be stated that the samples resemble capillary-porous and porous materials. The shape of the curves exhibit the characteristic of paper and textiles drying curves, although the total percentege of them didn't exceed $15 \%$. However the drying rate was twice more dynamic in RDF0 and RDF1 than in paper and textiles. The first period of drying, related to the constant drying rate occured in both of RDF samples, but it lasted a short time at the temperature 50 and $70{ }^{\circ} \mathrm{C}$. At the 90 ${ }^{\circ} \mathrm{C}$ the first drying period occured slightly in RDF1, but hardy in RDF1 (Fig. 4 - bottom plots of A and B). The first drying period was specific to the plastics olny (Fig. $3 \mathrm{C}$ ), which is the main component of the RDF (ok. 70 $\%$ ). The drying rate of RDF was faster in the shredded fraction (RDF1), where the area of of evaporation was larger due to reduction of particie size. At the $90{ }^{\circ} \mathrm{C}$ both of $\mathrm{RDF}$ samples were dried completely untill the moisture content of $\mathrm{U}=0$ (Fig 4, bottom plots of A and $\mathrm{B})$. At the lower temperatures the RDF resembled more party-hygroscopic material [9], it might contain the areas of a different moisture component. At lower temperatures $\mathrm{RDF}$ was dried to an eqiulibrum moisture content, which was $0.110 \mathrm{~kg}$ water $/ \mathrm{kg}$ d.b. at $\mathrm{T}=50{ }^{\circ} \mathrm{C}$ and $0.001 \mathrm{~kg}$ water $/ \mathrm{kg} \mathrm{d.b}$. at $\mathrm{T}=70{ }^{\circ} \mathrm{C}$ for $\mathrm{RDF} 0$, and $0.041 \mathrm{~kg}$ water $/ \mathrm{kg}$ d.b. $\mathrm{T}=50{ }^{\circ} \mathrm{C}$ i $0.010 \mathrm{~kg}$ water $/ \mathrm{kg}$ d.b. $\mathrm{T}=70{ }^{\circ} \mathrm{C}$ for $\mathrm{RDF} 1$ respectively.

Table 5. Empirical constants of the Henderson-Pabis, Levis and Page equasions of RDF0 and RDF1.

\begin{tabular}{|c|c|c|c|c|c|c|c|c|c|}
\hline \multirow[t]{2}{*}{ Sample } & \multirow{2}{*}{$\begin{array}{l}\text { Temp } \\
\left({ }^{\circ} \mathrm{C}\right)\end{array}$} & \multicolumn{3}{|c|}{ Henderson-Pabis equation } & \multicolumn{2}{|c|}{ Levis equation } & \multicolumn{3}{|c|}{ Page equation } \\
\hline & & $\mathbf{k}\left[\mathbf{s}^{-1}\right]$ & $\mathbf{a}$ & $\mathbf{R}^{2}$ & $k\left[s^{-1}\right]$ & $\mathbf{R}^{2}$ & $\mathbf{k}\left[\mathbf{s}^{-1}\right]$ & $\mathbf{N}$ & $\mathbf{R}^{2}$ \\
\hline \multirow[t]{3}{*}{ RDF0 } & 50 & $-4.93 \times 10^{-3}$ & 0.9238 & 0.9696 & $-5.90 \times 10^{-3}$ & 0.9239 & $5.57 \times 10^{-3}$ & 0.6617 & 0.9879 \\
\hline & 70 & $-1.68 \times 10^{-3}$ & 1.0982 & 0.9907 & $-1.59 \times 10^{-3}$ & 0.9937 & $2.47 \times 10^{-3}$ & 0.9254 & 0.9910 \\
\hline & 90 & $-4.10 \times 10^{-3}$ & 1.5709 & 0.7031 & $-1.59 \times 10^{-3}$ & 0.6598 & $4.28 \times 10^{-3}$ & 0.9312 & 0.9682 \\
\hline \multirow[t]{3}{*}{ RDF1 } & 50 & $-1.23 \times 10^{-3}$ & 0.0123 & 0.9950 & $-1.13 \times 10^{-3}$ & 0.9941 & $3.96 \times 10^{-3}$ & 0.8304 & 0.9934 \\
\hline & 70 & $-1.83 \times 10^{-3}$ & 0.9785 & 0.9997 & $-1.86 \times 10^{-3}$ & 0.9992 & $5.61 \times 10^{-3}$ & 0.8272 & 0.9890 \\
\hline & 90 & $-3.92 \times 10^{-3}$ & 1.5876 & 0.7152 & $-3.36 \times 10^{-3}$ & 0.9287 & $3.98 \times 10^{-3}$ & 0.9505 & 0.9808 \\
\hline
\end{tabular}

Table 6. Model prediction evaluation for the RDF0 and RDF1.

\begin{tabular}{|c|c|c|c|c|c|c|c|c|c|c|}
\hline \multirow[b]{2}{*}{ Sample } & \multirow{2}{*}{$\begin{array}{l}\text { Tem } \\
\mathbf{p} \\
\left({ }^{\circ} \mathrm{C}\right)\end{array}$} & \multicolumn{3}{|c|}{ Henderson-Pabis model } & \multicolumn{3}{|c|}{ Levis model } & \multicolumn{3}{|c|}{ Page model } \\
\hline & & RMSE & $\chi^{2} \times 10^{-3}$ & $\% \mathbf{E}$ & RMSE & $\chi^{2} \times 10^{-3}$ & $\% \mathbf{E}$ & RMSE & $\chi^{2} \times 10^{-3}$ & $\% \mathbf{E}$ \\
\hline \multirow[t]{3}{*}{ RDF0 } & 50 & 0.0221 & 4.921 & 2.50 & 0.0349 & 1.228 & 4.496 & 0.0139 & 0.195 & 1.8200 \\
\hline & 70 & 0.0253 & 6.440 & 5.32 & 0.0201 & 4.322 & 4.197 & 0.0249 & 0.621 & 11.583 \\
\hline & 90 & 0.1523 & 23.434 & 47.89 & 0.1630 & 26.711 & 62.73 & 0.0498 & 2.493 & 54.701 \\
\hline \multirow[t]{3}{*}{ RDF1 } & 50 & 0.0157 & 0.25 & 2.49 & 0.0170 & 0.291 & 3.480 & 0.0181 & 0.327 & 4.414 \\
\hline & 70 & 0.0046 & 0.002 & 1.18 & 0.0069 & 0.005 & 1.523 & 0.0259 & 0.677 & 9.140 \\
\hline & 90 & 0.1453 & 0.021 & 37.01 & 0.0633 & 4.008 & 42.811 & 0.0378 & 1.278 & 47.30 \\
\hline
\end{tabular}


Based on the results of the experiment the three methematical drying models were fit to the experimental data. The calculations are reveled in Table 5 and Table 6 . All of the models provided are a very good fit to the experimental data of drying RDF samples at various temperatures. Of all the models tested, the Page model offered the highest value for $\mathrm{R}^{2}$. However, the Henderson-Pabis and Levis models had a great fit at the temperatures of $50 \mathrm{i} 70^{\circ} \mathrm{C}$ as well. At the temperatures of $50-70{ }^{\circ} \mathrm{C}$ the value of $\mathrm{R}^{2}$ parameter with the Levis model reached above 0,98 for RDF0 $\mathrm{i}$ RDF1 samples (Table 5). The $\chi^{2}$ test values reflect to the goodness of model fit and are low (less than 0.02), but quite varied depending on samples types and the temperature of process in all three models (Table 6). The lowest $\chi^{2}$ test values were obtained from the Page model. The highest values of the $\chi^{2}$ test were related to the lowest values of $\mathrm{R}^{2}$ parameter and concerned the Henderson-Pabis and Levis models for modeling of drying RDF0 and RDF 1 at $90^{\circ} \mathrm{C}$.

The highest values of $\% \mathrm{E}$ parameter were obtained at the temperature $90{ }^{\circ} \mathrm{C}$, where they reached even $62 \%$ (Table 6). The drying ratio curve of RDF1 and RDF0 at $90{ }^{\circ} \mathrm{C}$ was more linear (Fig. 4 A,B) and it's deviation from values of lower temperatures propably was caused by describing it with exponential equations. Compared to RDF0, the values of \%E were lower in the RDF1 sample. Maybe from the comminuted sample, which RDF1 was, more homogeneous samples were aqcuired.

Table 7. Effective diffusivities for the RDF0 and RDF1.

\begin{tabular}{llrr}
\hline Sample & $\begin{array}{l}\text { Temp } \\
{\left[{ }^{\circ} \mathbf{C}\right]}\end{array}$ & $\begin{array}{l}\mathbf{D}_{\text {eff }} \\
{\left[\mathbf{m}^{2} \cdot \mathbf{s}^{-1}\right]}\end{array}$ & $\begin{array}{l}\mathbf{E}_{\mathbf{a}} \\
{\left[\mathbf{k J} \cdot \mathbf{m o l}^{-1}\right]}\end{array}$ \\
\hline RDF0 & 50 & $4.0457 \times 10^{-7}$ & 52.07 \\
& 70 & $13.7892 \times 10^{-7}$ & \\
& 90 & $33.6521 \times 10^{-7}$ & \\
\hline RDF1 & 50 & $10.0707 \times 10^{-7}$ & 28.26 \\
& 70 & $15.0547 \times 10^{-7}$ & \\
& 90 & $32.1453 \times 10^{-7}$ & \\
\hline
\end{tabular}

The raise in effective moisture diffusivity $D_{\text {eff }}$ was related to increasement of the temperature and decreasement of the paticle size of the samples. At 50 ${ }^{\circ} \mathrm{C}$ in RDF1 was almost two times higher than in RDF0 and was about $10.0707 \times 10^{-7}\left[\mathrm{~m}^{2} \cdot \mathrm{s}^{-1}\right]$ (Table 7). The activation energy $\left(E_{a}\right)$ for diffusion calculated from the slopes of normalized equation of $\mathrm{D}_{\text {eff }}(10)$ was found to be $52.07 \mathrm{~kJ} \cdot \mathrm{mol}^{-1}$ for RDF0 and $28.26 \mathrm{~kJ} \cdot \mathrm{mol}^{-1}$ for RDF1. Comminution of the RDF resulted in a decrease in activation energy.

\section{Conclusions}

1) The paper and textiles had the highest moisture content in RDF composition of $41 \%$ and $22 \%$ respectively. Moisture content of the plastic did nor exceed $10 \%$. The comminution of RDF caused insignificant difference in the moisture content between RDF0 and it's shredded form of RDF1.

2) Based on the analysis of the drying kinetics of the RDF0 and RDF1 it could be stated that RDF has more features of porous material than porous-capillary. The first period of drying occured only in plastic and slightly in RDF0 and RDF1 at lower drying temperatures of 50 and $70{ }^{\circ} \mathrm{C}$. The drying process begun with second period of drying in paper and textiles. The moisture and mass movement was mainly by diffusion and less by capipillary for ces.

3) Of all of the three drying kinetics models of RDF tested, the Levis model had the best fit to the experimental data. The obtained values for $\mathrm{R}^{2}$ was greater than 0.98 and $\chi^{2}$ test values were in the range of $0.3-2,4 \times 10^{-3}$. None of the mathematical models were able to satisfactory describe the performance of drying RDF at the temperature of $90^{\circ} \mathrm{C}$.

4) The Effective moisture diffusivity $\left(D_{\text {eff }}\right)$ values were affected by increasing temperature. The highest values of $33.6521 \times 10^{-7} \mathrm{~m}^{2} \cdot \mathrm{s}^{-1}$ were obtained at $90{ }^{\circ} \mathrm{C}$, and the lowest of $4.0457 \times 10^{-7} \mathrm{~m}^{2} \cdot \mathrm{s}^{-1}$ were obtained at $50{ }^{\circ} \mathrm{C}$ for RDF0. The Activation energy $\left(\mathrm{E}_{\mathrm{a}}\right)$ varied from $28.26 \mathrm{~kJ} \cdot \mathrm{mol}^{-1}$ to $52.07 \mathrm{~kJ} \cdot \mathrm{mol}^{-1}$ for RDF1 and RDF0 respectively. The lower energy is needed to remove water from comminuted RDF.

5) Drying process of the RDF using hot air at the temperature of $90 \mathrm{RDF}{ }^{\circ} \mathrm{C}$ allows for removal of the moisture content completely, until $\mathrm{U}=0$. At lower temperatures of $50{ }^{\circ} \mathrm{C}$ and $70{ }^{\circ} \mathrm{C}$ the RDF could be dried untill the equillibrium moisture content.

This work was supported by funds of a specific grant for development of young scientists of the Hugo Kołłątaj University of Agriculture in Kraków (grant number BM4633/2016) and the Laboratory of Production Technology and Quality Estimation of Biofuels in the Chair of Mechanical Engineering and Agrophysics at the University of Agriculture in Kraków.

\section{Nomenclature}

$\begin{array}{ll}\mathrm{E}_{\mathrm{a}} & \text { activation energy, } \mathrm{kJ} \cdot \mathrm{mol}^{-1} \\ \mathrm{D}_{\mathrm{eff}} & \text { effective moisture diffusivity, } \mathrm{m}^{2} \cdot \mathrm{s}^{-1} \\ \mathrm{D}_{0} & \text { pre-exponential factor of the Arrhenius equation, } \mathrm{s}^{-1} \\ \mathrm{~d} . \mathrm{s} . & \text { dry solid } \\ \mathrm{k} & \text { drying rate constant, } \mathrm{s}^{-1} \\ \mathrm{MR} & \text { moisture ratio (dimensionless) } \\ \mathrm{N} & \text { number of obserwations } \\ \mathrm{U}_{\tau} & \text { moisture content at any time, } \mathrm{kg} \text { water/ } \mathrm{kg} \mathrm{d.s} \\ \mathrm{U}_{\mathrm{i}} & \text { initial moisture content (dry basis), } \mathrm{kg} \text { water } / \mathrm{kg} \mathrm{d.s.} \\ \mathrm{U}_{\mathrm{e}} & \text { equilibrum moisture kontent, } \mathrm{kg} \mathrm{water} / \mathrm{kg} \mathrm{d} . \mathrm{s} \\ \mathrm{T} & \text { absolute temperature, } \mathrm{K} \\ \tau & \text { time, } \mathrm{s}\end{array}$

\section{References}

[1] Schwarzböck T. et al. (2016), Fuel Processing Technology 153, 101-110 (2016)

[2] E. Iacovidou, J. Hahladakis, I. Deans, C. Velis, P. Purnell, Waste Management, http://dx.doi.org/10.1016/j.wasman.2017.07.001, (2017) 
[3] M. Nasrullah, M. Hurme, P. Oinas, J. Hannula, P. Vainikka, Fuel Processing Technology 163 (2017)

[4] M. Malinowski, Infrastructure and Ecology of Rural Areas, Nr 2/IV/2013, PAN, Oddział w Krakowie, 125-139, (2013)

[5] Ö. Çepelioğullar, H. Haykırı-Açma, S. Yaman, Waste Management, 48, 275-284, (2016)

[2] Materazzi et al., Fuel 150, 473-485 (2016)

[6] C. Bessi, L. Lombardi, R. Meoni, A. Canovai, A. Corti, Waste Management 47 (2016)

[7] M. Malinowski, Episteme 14/2012, 101-108, ISSN 1895-4421, (2012)

[8] K. Dziedzic, B. Łapczyńska-Kordon, M. Malinowski, M. Niemiec, J. Sikora, Chemical and Process Engineering, 36 (4), 381-384, (2015)

[9] C.A. Velis , P.J. Longhurst, G.H. Drew , R. Smith, S.J.T. Pollard, Production and Quality Assurance of Solid Recovered Fuels Using Mechanical-Biological Treatment (MBT) of Waste: A Comprehensive Assessment, Critical Reviews in Environmental Science and Technology, 40:12, 979-1105, DOI: 10.1080/10643380802586980, (2010)

[10] R. Wasielewski, S. Stelmach, A. Sobolewski, Chemik, 65, 6, 572-579, (2011)

[11] J. Frączek, K. Słomka-Polonis, K. Mudryk, M. Wróbel, K. Dziedzic, Agricultural Engineering, Vol. 20, No.4, 207-217, (2016)

[12] Stowarzyszenie Producentów Cementu (SPC). Paliwo alternatywne na bazie sortowanych odpadów komunalnych dla przemystu cementowego. Kraków, 3. (2008)

[13] N.P.K. Nielsen, D.J. Gardner, T. Poulsen, C. Felby. Wood Fiber Sci, 41:414, (2009)

[14] H.J.K. Köser, G. Schmalstieg, W. SiemersFuel, 61:791-8, (1982)

[15] J. Frączek, K. Mudryk, Acta Agrophysica, 14(1) (2009)

[16] A. Yasuhara, Y. Amanoa, T. Shibamoto, Waste Management 30, 1161-1164, (2010)

[17] E. Golisz, M. Jaros, M. Kalicka, Technical Sciences 16(4), 333-343, (2013)
[18] Y. Tulek, J. Agr. Sci. Tech. Vol. 13: 655-664, (2011)

[19] C. Strumiłło, Inżynieria Chemiczna: Podstawy teorii i techniki suszenia. Wyd. Naukowo-Techniczne, Warszawa, ISBN 83-204-0418-5, (1983)

[32] F. Kneulle, Suszenie. Arkady, Wyd. Warszawa, (1970)

[20] J. Fraczek J. red., Wyd. PTIR, Kraków 2010, ISBN: 978-83-930818-0-6, (2010)

[21] B.Dobrzański, L. Mieszalski, ISBN-13: 978-8360489-06-2, (2007)

[22] O.C.Motta Lima, N.C.Pereira and M.A.L.S.Machado, Brazilian Journal of Chemical Engineering, 17(4-7), 539-548. https://dx.doi.org/10.1590/S010466322000000400018, (2000)

[23] W. Yu, X. Liu, H.S. Su, Y.J. Zhang, Energy and Power Engineering, 9, 141-148. https://doi.org/10.4236/epe.2017.94B017, (2017)

[24] M.G.A. Vieira, L. Estrella, S.C.S. Rocha, Drying Technology: An International Journal, 25:10, 16391648, DOI: 10.1080/07373930701590806, (2007)

[25] L. Helena, C.D. Sousa, O.C. Motta Lima, N.C. Pereira, Drying Technology, 24: 485-497, DOI: 10.1080/07373930600611984, (2006)

[26] Y. Choi, B. Jung, N. Sung, Y. Han, J Mater Cycles Waste Manag, DOI 10.1007/s10163-014-0248-8, (2014)

[27] (niepublikowane badania Frączek, Wróbel Modeling of RDF pelletization proces, 2016)

[28] PN-EN ISO 638:2008 - Paper, board and pulps Determination of dry matter content - Oven-drying method (ISO 638:2008)

[29] PN-EN 15414-3:2011 - Solid recovered fuels Determination of moisture content using the oven dry method - Part 3: Moisture in general analysis sample

[30] J.S. Roberts, D.R. Kidd, O. Padilla-Zakour, Journal of Food Engineering, 89, 460-465, (2008)

[31] C.J. Lomauro, A.S. Bakshi, T. P. Labuza, Journal of Food Science, Volume 50 (1985) 